\title{
Tricholosporum caraibicum (Basidiomycota, Tricholomataceae), a new species from the Dominican Republic
}

\author{
Angelini $\mathbf{C}^{\mathbf{1}}$, Contu $\mathrm{M}^{\mathbf{2}}$ and Vizzini $\mathrm{A}^{3^{*}}$ \\ ${ }^{1}$ Via Tulipifero 9, I-33080, Porcia (PN), Italy \\ ${ }^{2}$ Via Marmilla 12, I-07026, Olbia (OT), Italy \\ ${ }^{3}$ Dipartimento di Scienze della Vita e Biologia dei Sistemi, Università di Torino, Viale P.A. Mattioli 25, I-10125, \\ Torino, Italy
}

Angelini C, Contu M, Vizzini A 2014 - Tricholosporum caraibicum (Basidiomycota, Tricholomataceae), a new species from the Dominican Republic. Mycosphere 5(3), 430-439, Doi 10.5943/mycosphere/5/3/6

\begin{abstract}
A new species in the genus Tricholosporum, collected in the Dominican Republic, is taxonomically delimited based on morphological data. A detailed description, microscopic drawings and a colour plate of fresh material are presented. The new species is well circumscribed by the small cruciform to stauriform spores and mucronate, fusiform to ampullaceous and pigmented cystidia. A key to the accepted species of Tricholosporum is provided.
\end{abstract}

Key words - Agaricales - Agaricomycetes - Caribbean fungi

\section{Introduction}

The genus Tricholosporum was established by G. Guzmán to accommodate Tricholoma goniospermum Bres. and Tricholosporum subporphyrophyllum Guzmán, based on the difference in their spore shape, compared to that of true Tricholoma (Fr.) Staude species (Guzmán 1975). Singer (1986), however, did not recognize Tricholosporum as a distinct genus and placed Tricholoma goniospermum and allied species, such as as Tricholoma porphyrophyllum S. Imai, Tricholosporum subporphyrophyllum and Gymnopus atroviolaceus Murrill in Tricholoma (Fr.) Staude section Iorigida Singer, typified by Tricholoma pseudosordidum Singer, an opinion shared, among others, by Bohus (1985). In Bon's (1991) taxonomic account of the European species of Tricholoma, Tricholosporum is treated as a subgenus of Tricholoma (see also Bon \& Braiotta 1989, where the new combination Tricholoma subgen. Tricholosporum is firstly introduced).

In recent years most authors treated Tricholosporum as a genus in its own right (Baroni 1982, Halling \& Franco Molano 1996, Reid et al. 1998, Bohus et al. 1999, Contu \& Mua 2000, Boisselet \& Moreau 2008, Riva 2008, Fernandez Vicente et. al. 2010, Christensen \& HeilmannClausen 2013) and in the present paper this opinion is followed. Unfortunately no molecular analysis has included species of the genus. Tricholosporum appears to be a widespread genus as members are known from North and South America, Africa, Asia, Canary Islands and Europe (Contu \& Mua 2000). Tricholosporum can be distinguished from Tricholoma based on the rhomboid to cruciform spores (Baroni 1982, Guzmán 1975, 1994, Contu \& Mua 2000).

During field work in the Dominican Republic in late 2013, basidiomata of a very beautiful agaric were collected; close micromorphological examination revealed the presence of cruciform 
basidiospores and a lack of siderophilous grana in the basidia, suggesting that the specimens belong to the genus Tricholosporum.

No name being available for this very remarkable agaric, we therefore describe it as a new species, Tricholosporum caraibicum

\section{Materials \& Methods}

Macroscopic descriptions were based on the study of fresh material by the first author. A total of 6 basidiomes were studied. The microscopic descriptions and the micromorphological data are based on herbarium material reinflated by using water and L4 and coloured with Congo Red and Phloxin B. Cotton Blue was utilized to examine the siderophilous grana in the basidia and to detect gelatinised tissues in the pileal surface. Spore measurements are based on means of 32 spores, originating from three basidiomes. The taxonomy of Baroni (1982) was followed for the description of the new species. The Latin description of the new species was deposited in Mycobank (http://www.mycobank.org/DefaultPage.aspx). Herbarium acronyms follow Thiers (2014). Author citations follow the Index Fungorum, Authors of Fungal Names (www.indexfungorum.org/authorsoffungalnames.htm).

\section{Results}

Tricholosporum caraibicum Angelini, Contu \& Vizzini, sp. nov.

Figs $1-7$ MycoBank MB808819

Etymology - named after the geographic area where the type-specimen has been collected.

Pileus 30-40 mm latus, parce carnosus, convexus, ad medium obtuse umbonatus, haud hygrophanus, violaceo-lilacinus deinde ad medium flavescens, feltroso-fibrillosus, siccus, haud striatus. Lamellae sat confertae, emarginato-adnexae, violaceae, tactu flavescentes. Stipes 40-50 $\times$ 6-7mm, cylindricus, ad basim leviter inflatus vel attenuatus, cyaneo-violaceus, fibrillosus, pruinosus, superne pruinoso-floccusus. Caro parce conspicua, cremea in pileo flavescens, in stipite cremeo-violacea, immutabilis. Odor fungicus, sapor similis sed deinde satis amarus. Sporae (3.7) 4.1-5 × (3.2-)3.4-4 um, hyalinae, cruciformes vel stellatae, tenuitunicatae. Basidia 25-30 × 5-7 $\mu \mathrm{m}$, tetraspora. Cheilocystidia et pleurocystdia 18-42 $\times 3-11.2 \mu \mathrm{m}$, simillima, plerumque ampullacea, apex rotundatus, lanceolatus vel mucronatus, interdum fusiformia, griseo-violacea. Pilei cutis ex hyphis laxe intertextis, passim ascendentibus, 4-9 $\mu \mathrm{m}$ lat. efformata, suprapellis gelata. Fibulae numerosae. Typus: Dominican Republic, Sosua (P.to Plata), 16.XII.2013, leg. C. Angelini (herb. JBSD 125216, holotypus).

Habit resembling that of Calocybe ionides/Lepista sordida.

Pileus 30-40 mm, not very fleshy, not cartilaginous, convex, then plano-convex, widely and obtusely umbonate, the margin involute for a long time, dry, opaque, not hygrophanous, at first fibrillose-felted (due to very thin, white hairs) then finely velvety but smooth towards the centre, deeply violaceous-lilac (but fading yellow to citrine-yellow at the centre on age with the margin remaining violet), with peculiar white or yellowish elongated spots or maculae. Lamellae (with lamellulae) slightly ventricose, normally crowded to crowded, thickish, emarginate-adnexed, violaceous, yellowing when handled, with concolorous and slightly eroded edge. Stipe 40-50 × 6-7 $\mathrm{mm}$, solid, fistulose-hollow, cylindric, sometimes enlarged or tapered downwards, bluishviolaceous, fading to whitish on age, especially toward the base, adpressed fibrillose, covered by an abundant white flocculose pruina which is more abundant and intermixed with flocci at the apex, the base with thin, white rhizomorphous filaments. Context thin, 2-3 mm thick, cream yellowing in the pileus, cream-violaceous and unchanging in the stipe. Smell not peculiar, fungineous, taste at first similar but then rather strongly bitter. Edibility unknown. Spore-print: white.

Spores $[\mathrm{n}=32](3.7-) 4.1-5 \times(3.2-) 3.4-4 \mu \mathrm{m}$, on average $4.1 \times 3.8 \mu \mathrm{m}, \mathrm{Qm}=1.2$, hyaline, thin-walled, inamyloid, not cyanophilous, cruciform to stauriform, usually with a single large oil-drop. Basidia 25-30 × 5-7 $\mu \mathrm{m}$, four-spored, mostly clavate, some sinuose or constricted, without siderophilous grana but with refracting yellow inclusions, sometimes also entirely yellow 


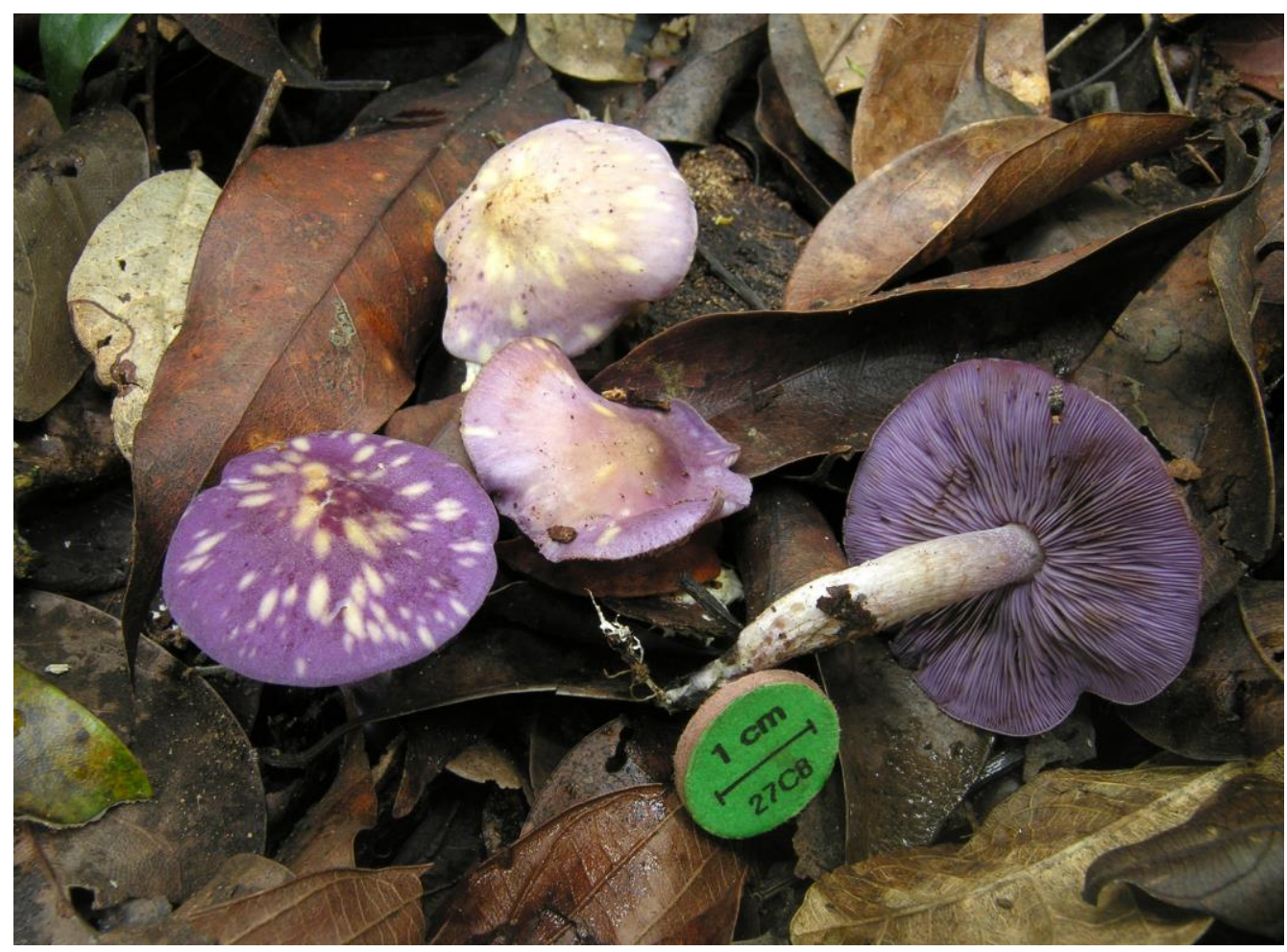

Fig. 1 - Tricholosporum caraibicum. Basidiomata (Holotype). This picture is copyright of Claudio Angelini.

due to a easily dissolved plasmatic pigment; subhymenium cellular. Hymenophoral trama regular, inamyloid, not dextrinoid, made up of thin greyish-violet, cylindrical hyphae, up to $8 \mu \mathrm{m}$ wide. Cheilocystidia and pleurocystidia similar, 18-42 $\times 3-11.2 \mu \mathrm{m}$, arising from subhymenium and protruding beyond the hymenial palisade, mostly ampullaceous, with a swollen base and a neck, up to $6 \mu \mathrm{m}$ wide, which is rounded, acute or mucronate at apex; less frequently fusiform or clavate (and then smaller: $16.5-25 \times 4.5-6 \mu \mathrm{m}$ ), thin- to slightly thick-walled, usually with a plasmatic grey-violet pigment, not dextrinoid. Pileipellis consisting of a cutis of loosely interwoven, grayviolet, cylindric to clavate, $4-9 \mu \mathrm{m}$ wide hyphae with all the kinds of transition to a trichodermium of erect hyphae; it is usually consisting of a true trichodermium in the portions of pileal surface in which hairs are present; suprapellis a thin ixocutis. Pileus trama hyaline, made up of cylindrical, wider hyphae with thick, brown walls. Stipe surface an undifferentiated cutis of vertically oriented, parallel hyphae, smooth, thin-walled, without caulocystidia. Stipe trama monomitic. Clamp connections present at all septa.

Habitat and known distribution - Gregarious, on soil in deciduous forest. Autumn. Very rare and so far known only from Dominican Republic.

Material examined - Dominican Republic, Santo Domingo, Jardin Botanico Nacional, 18.XI.2013, leg. C. Angelini, (herb. Angelini ANGE99); -- ditto, Sosua (P.to Plata), 16.XII.2013, leg. C. Angelini (herb. JBSD 125216, holotypus).

\section{Discussion}

Tricholosporum caraibicum is characterized by a unique combination of features such as small to medium sized basidiomata, a Calocybe like habit, a deep violaceous-lilac, fibrillose-felted or hairy-felted to velvety pileus, which is mottled with elongated yellowish-white spots, a bluishviolaceous stipe covered with a white pruina, which is more abundant at the apex. It has small, not exceeding $6 \mu \mathrm{m}$ in length, cruciform or stauriform spores, variable, versiform, mucronate to ampullaceous cystidia with grey-violet content and swollen bases arising from the subhymenium. The upper layer of the pileal surface consists of loosely interwoven to ascending, mostly clavate, gray-lilac to dark violaceous hyphae which are immersed in a more or less thin gelatinous matrix. 

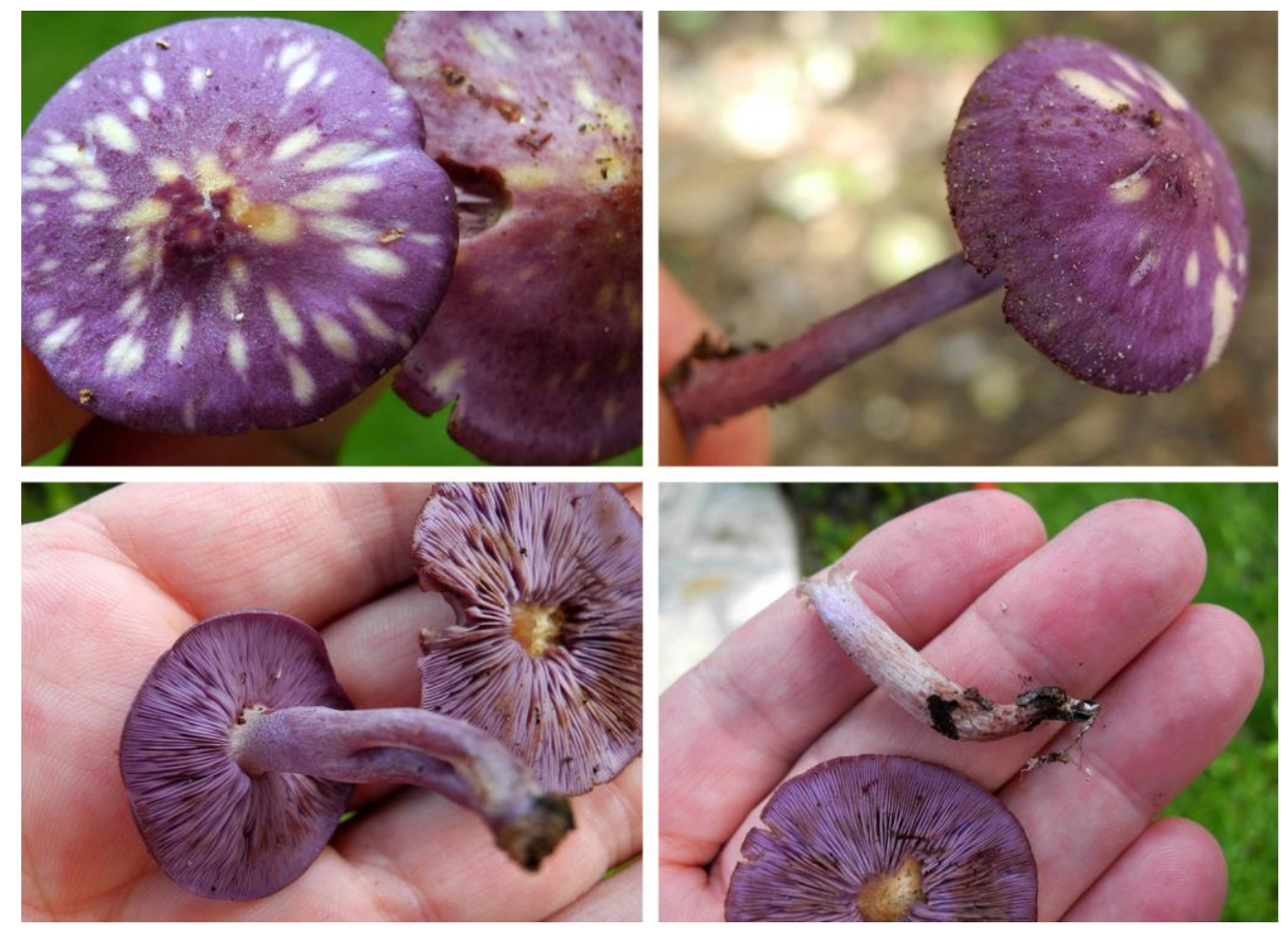

Fig. 2 -Tricholosporum caraibicum. Basidiomata (Holotype). This picture is copyright of Claudio Angelini.

Based on spore-size and cystidia-morphology, four groups of species can be distinguished in Tricholosporum, viz:

A) group 1: large spored-species, with spores over $7 \boldsymbol{\mu m}$ in length.

This group is the richest and comprises T. goniospermum (Bres.) Guzmán ex T.J. Baroni (Bresadola 1892, Josserand 1949, Riva 2008), T. laeteviolaceum D. Reid, Eicker, Clemençon \& Cec. Roux (Reid et al. 1998), T. longicystidiosum Guzmán, Montoya \& Bandala (Guzmán et al. 1990), T. porphyrophyllum (S. Imai) Guzmán ex T. J. Baroni (Imai 1938, Guzmán 1975, Hongo 1988), T. subgoniospermum Bohus, Vasas \& Locsmàndi (Bohus et al. 1999), $T$. subporphyrophyllum Guzmán (Guzmán 1975) and T. tetragonosporum (Maire) Contu \& Mua (Maire 1924, Bon \& Braiotta 1989, Contu \& Mua 2000, Boisselet \& Moreau 2008).

B) group 2: species with small spores, usually under $6 \mu \mathrm{m}$ in length.

subgroup 2.1: species devoid of hymenial cystidia.

This group comprises only T. atroviolaceum (Murrill) T.J. Baroni (Murrill 1938, Baroni 1982).

subgroup 2.2: species with hyaline hymenial cyistidia.

This group encompasses T. cossonianum (Maire) P.A. Moreau \& Contu (Maire 1945, Bohus 1985, Moreau \& Contu 2007), T. pseudosordidum (Singer) T. J. Baroni (Singer 1945, Baroni 1982) and T. tropicale Guzmán, Bandala \& Montoya (Guzmán et al. 1994). In addition they are characterized by a pileipellis as a cutis of repent hyphae.

subgroup 2.3: species with pigmented hymenial cystidia, which are grey-violet or brownish.

T. palmense J. Fernandez Vicente, P. Iglesias, P. Arauzo, F. Hidalgo \& M. Oyarzabal (Fernandez Vicente et. al. 2010) and T. violaceum Halling \& Franco-Molano (Halling \& FrancoMolano 1996) belong to this group.

As $T$. caraibicum shows spores under $6 \mu \mathrm{m}$ in length and pigmented hymenial cystidia, it takes place in this last subgroup. Tricholosporum violaceum, described from Costa Rica differs mainly in having a tricholomoid habit, rhomboid spores and fusiform to fusiform-mucronate not ampullaceous cystidia (Halling \& Franco-Molano 1996), whilst T. palmense, described from Canary Islands (Spain), also with usually ampullaceous cystidia, differs in having entirely pruinose and stout basidiomes resembling those of Lepista glaucocana (Bres.) Singer [our species, instead, 


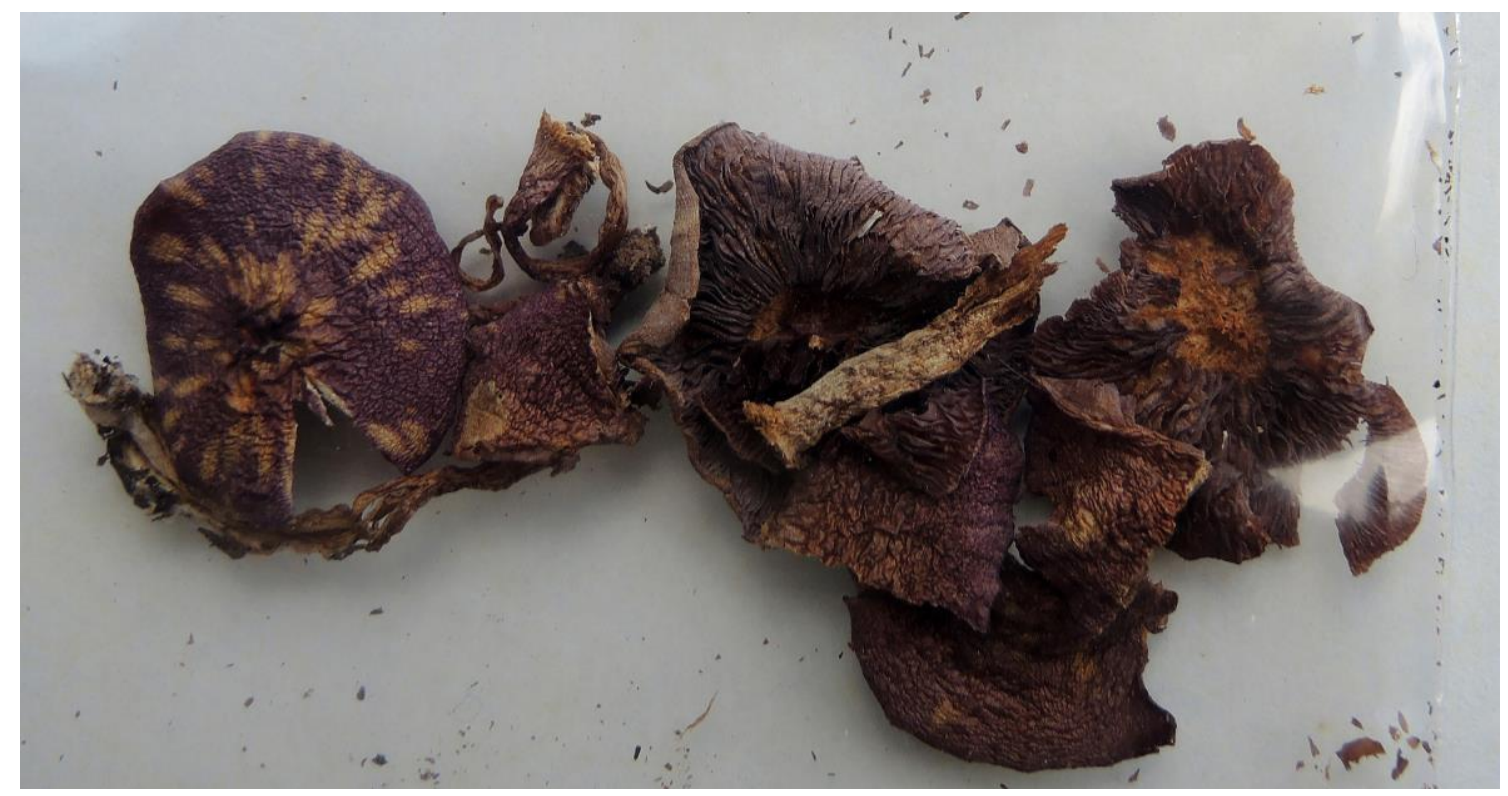

Fig. 3 - Tricholosporum caraibicum. Herbarium collection (Holotype). This picture is copyright of Claudio Angelini.
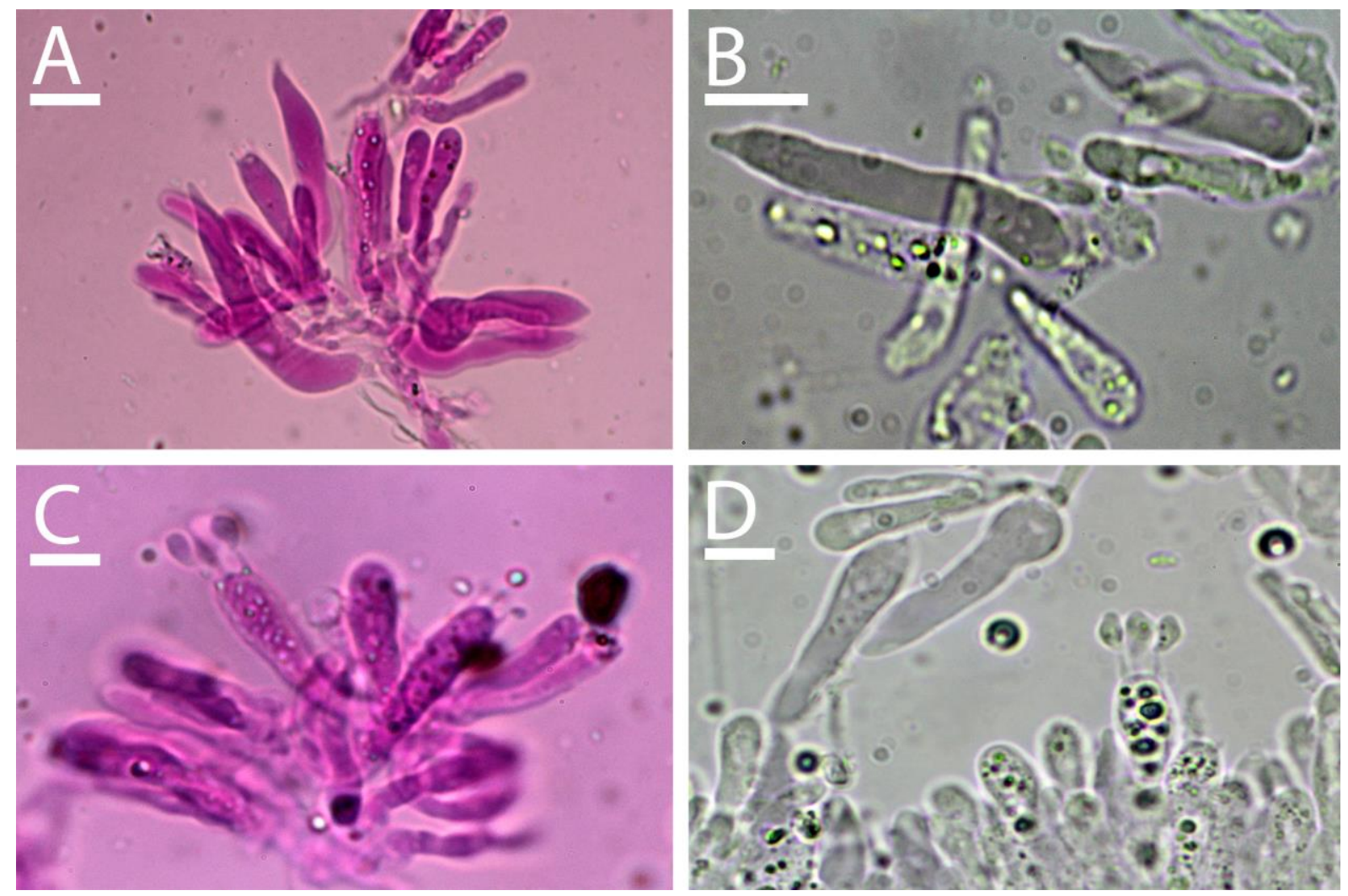

Fig. 4 - Tricholosporum caraibicum. Microscopic features (Holotype). A-B Pleurocystidia (Phloxin B and water); C-D Basidia (Phloxin B and water). - Bars $=10 \mu \mathrm{m}$

shows frail basidiomes reminding of Calocybe ionides (Bull.) Donk or Lepista sordida (Schumach.) Singer], a smooth, not yellow-spotted pileus surface, the more elongate cystidia, "31$53 \times 3.6-10 \mu \mathrm{m}$ ", which typically have a bi- or trifurcate apex and the upper layer of the pileal surface consisting of a cutis of slenderer, not clavate and never forming a trichodermium, hyaline hyphae (Fernandez Vicente et. al. 2010). Additionally, in T. palmense caulocystidia are present in the stipe surface and the context does not stain yellow. 

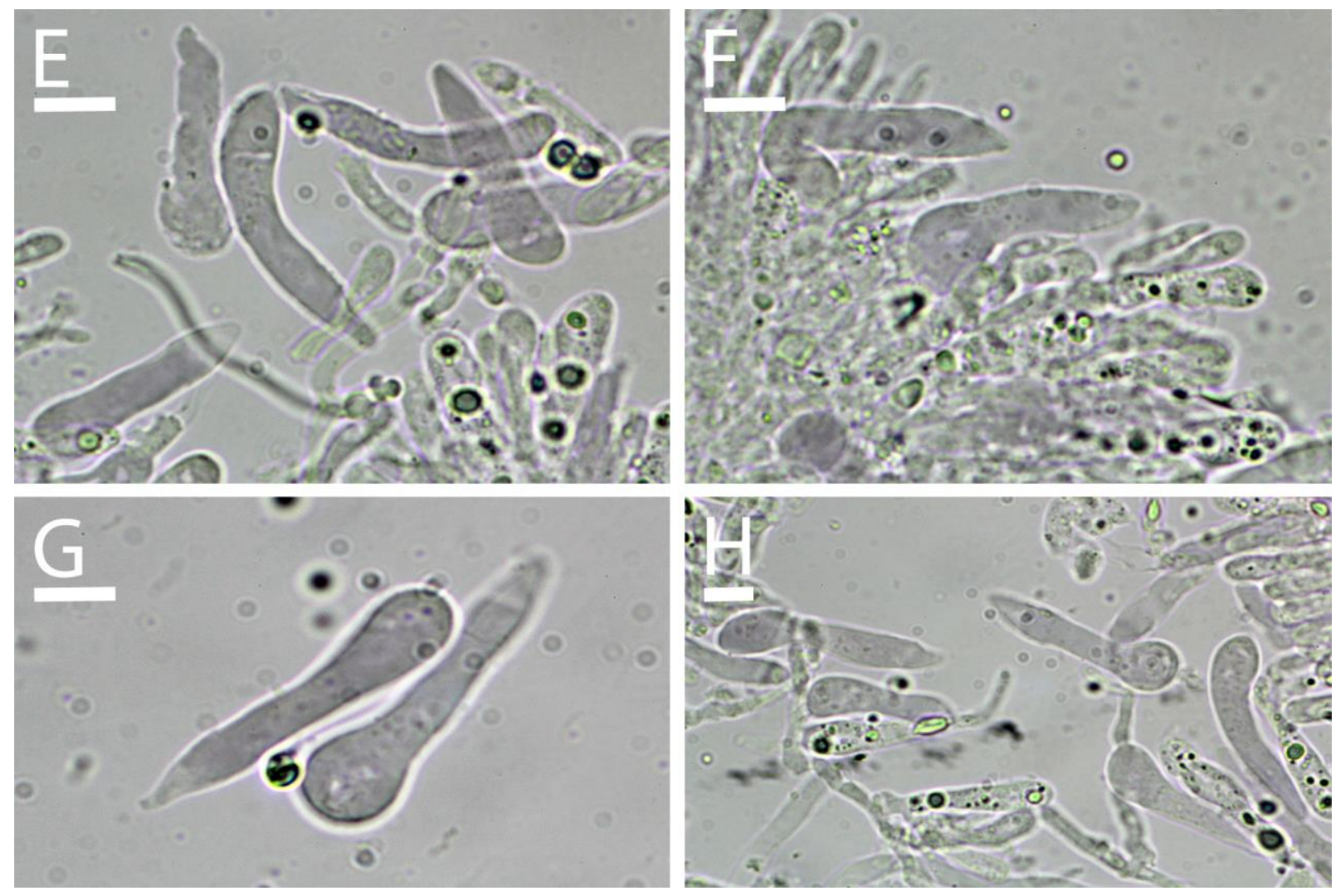

Fig. 5 - Tricholosporum caraibicum. Microscopic features (Holotype). E-H Cheilocystidia (water).

- Bars $=10 \mu \mathrm{m}$
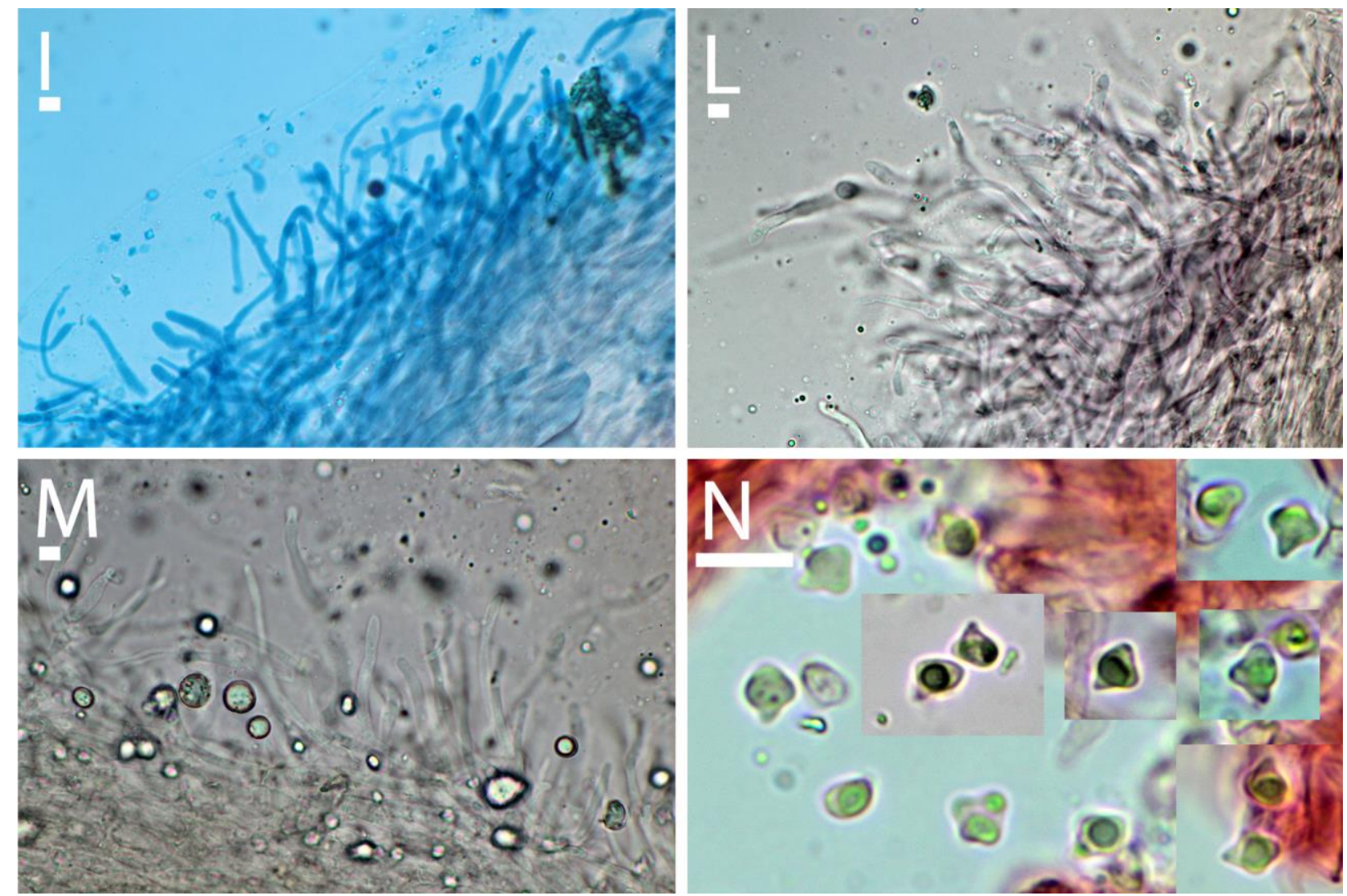

Fig. 6 - Tricholosporum caraibicum. Microscopic features (Holotype). I-M Pileipellis (Cotton Blue, water); N Spores (Congo Red). - Bars $=10 \mu \mathrm{m}$ 


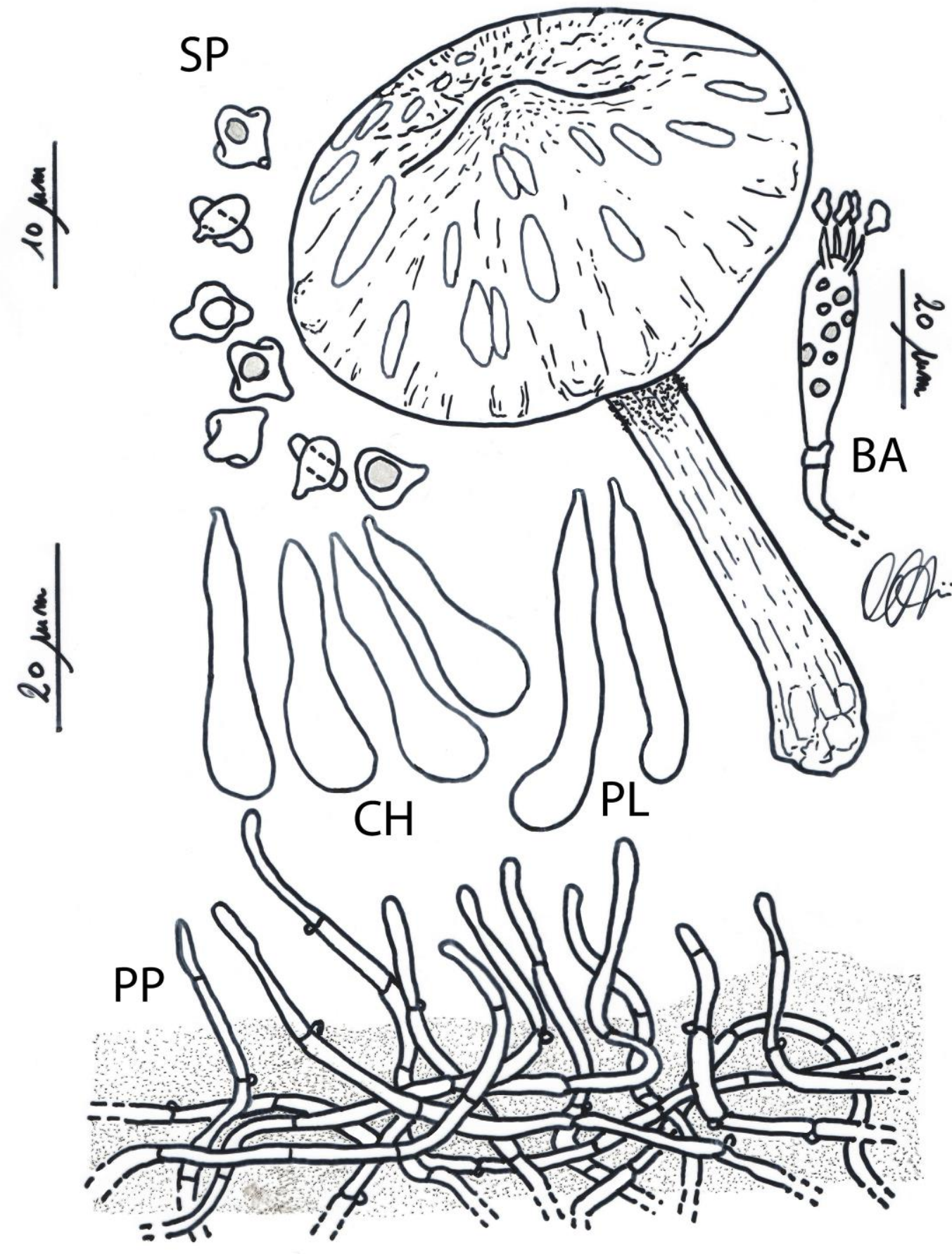

Fig. 7 - Tricholosporum caraibicum. Microscopic features (Holotype). SP Spores; BA Basidia; $\mathrm{CH}$ Cheilocystidia; PL Pleurocystidia; PP Pileipellis. Line drawings by Claudio Angelini.

It should be noted that two further species, viz "Tricholosporum" superbum Watling, from Malaysia (Watling 1997) and "Tricholoma" nodulosporun Babos \& Bohus (Bohus 1982, 1985, Contu \& Mua 2000, Guzmán et al. 2004), from Hungary, have been described or placed in the genus Tricholosporum but as both of them possess nodulose, not cruciform spores, they belong to the genus Asproinocybe Heim (Heim 1970, Heinemann \& Thoen 1977, Singer 1986, Heinemann 1997, Thoen 1997, Guzmán et al. 1994, 2004). 


\section{Key to the accepted species of Tricholosporum}

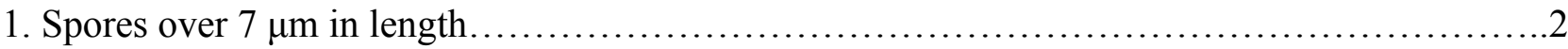

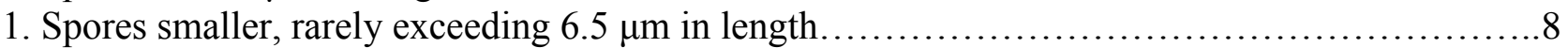

2. Hymenial cystidia absent, spores up to $10 \times 7 \mu \mathrm{m} \ldots \ldots \ldots \ldots \ldots \ldots \ldots \ldots \ldots$. porphyrophyllum

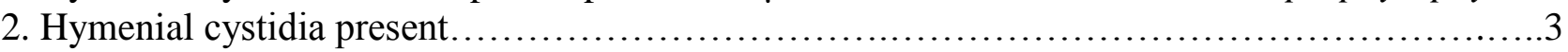

3. Spores $8-10 \times 5-7 \mu \mathrm{m}$, in grasslands....................................... goniospermum

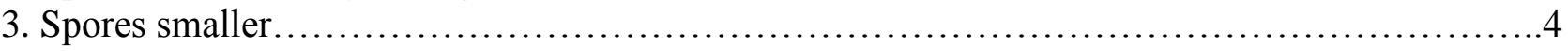

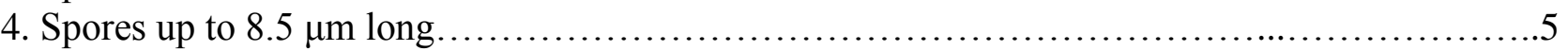

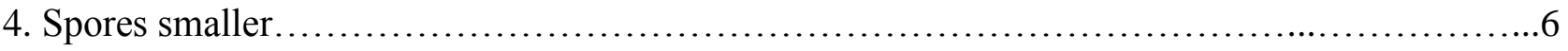

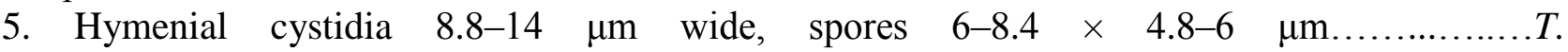
subporphyrophyllum

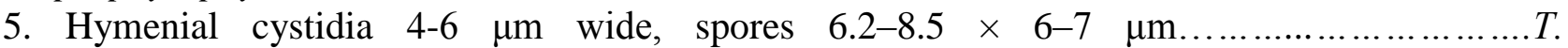
laeteviolaceum

6. Hymenial cystidia over $40 \mu \mathrm{m}$ in length and up to $12 \mu \mathrm{m}$ wide

T. longicystidiosum

6. Hymenial cystidia smaller, usually not exceeding $40 \mu \mathrm{m}$ in length............................

7. Spores 5.7.8 $\times 4-6 \mu \mathrm{m}$, in frondose woods, Eastern Europe..................... subgoniospermum

7. Spores 5.5-7 $\times 5-6 \mu \mathrm{m}$, in sandy soils, mainly in coastal conifer woods........T. tetragonosporum

8. Hymenial cystidia absent................................................ atroviolaceum

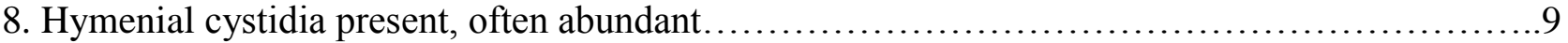

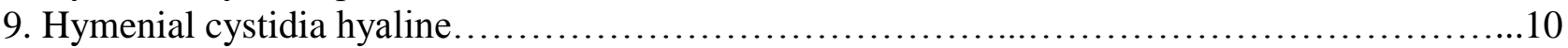

9. Hymenial cystidia with violet, lilac or greyish-lilac content..............................

10.Violet tinges present only in the stipe of young basidiomes but soon disappearing, pileus grey to brownish-gray, spores obscurely angular to very slightly subcruciform............... cossonianum 10.Basidiomes with violet tinges also in the pileus, spores definitely cruciform.

11. Hymenial cystidia up to $28 \times 6 \mu \mathrm{m}$, rare, small species resembling tiny basidiomes of Lepista sordida T. pseudosordidum 11.Hymenial cystidia up to $40 \times 7.2 \mu \mathrm{m}$, abundant, more robust species................ tropicale 12.Spores $5.5-6.7 \times 4.4-5.9 \mu \mathrm{m}$, cystidia often with furcate apex...................... palmense

12. Spores definitely smaller, not over $5 \mu \mathrm{m}$ long, cystidia without furcate apex .13 13. Spores mostly rhomboid, not cruciform, cystidia up to $60 \times 9 \mu \mathrm{m}$, pileal surface smooth and glabrous.......................................................................... violaceum 13. Spores cruciform to stauriform, cystidia up to $42 \times 11.2 \mu \mathrm{m}$, pileal surface fibrillosefelted. T. caraibicum

\section{Acknowledgements}

We wish to thank F. Jimenez, A. Veloz and R. Garcia (Jardín Botánico Nacional dr. Rafael Ma. Moscoso - Santo Domingo - Dominican Republic) for their interest and encouragement to study the fungi of the Dominican Republic and for their active cooperation in putting at our disposal material in the Herbarium of the Botanical Garden of Santo Domingo.

\section{References}

Baroni TJ. 1982 - Tricholosporum and notes on Omphaliaster and Clitocybe. Mycologia 74, 865871.

Bohus G. 1982 - Some results of systematical and ecological research in Agaricales. Studia Botanica Hungarica 16, 41-47.

Bohus G. 1985 - Tricholoma section Iorigida Sing. in Europe and North-Africa. Agarica 12 (6), 381-386. 
Bohus G, Vasas G, Locsmandi CS. 1999 - Two new fungus species from Hungary (Basidiomycetes, Agaricales). Annales Historico-Naturales Musei Nationalis Hungarici 91, 37-44.

Boisselet P, Moreau PA. 2008 - Tricholosporum tetragonosporum (Maire) Contu \& Mua récolté en Ardèche. Bulletin mycologique et botanique Dauphiné-Savoie 189, 17-21.

Bon M. 1991 - Les tricholomes et ressemblants. Flore mycologique d'Europe 5. Documents mycologiques. Mémoires hors-série 2, 1-161.

Bon M, Braiotta G. 1989 - Tricholoma goniospermum forma tetragonosporum (Maire) Bon, comb. nov. Documents Mycologiques 19 (75), 49-52.

Bresadola G. 1892 - Fungi Tridentini Novi vel Nondum Delineati. II. Trento.

Christensen M, Heilmann-Clausen J. 2013 - Fungi of Northern Europe. 4. The genus Tricholoma. Narayana Press, Gylling.

Contu M, Mua A. 2000 - Il genere Tricholosporum Guzmán (Basidiomycotina, Agaricomycetes) in Europa. Rivista di Micologia 2000 (3), 249-257.

Fernandez Vicente J, Iglesias P, Hidalgo F, Oyarzabal M. 2010 - Aportaciones al conocimiento micologico de la Isla de La Palma II y una nueva especie de Tricholosporum. Errotari 7, 84131.

Guzmán G. 1975 - Un nuevo género y dos nuevas especies de Agaricaceos mexicanos. Boletín de la Sociedad Mexicana de Micologia 9, 61-66.

Guzmán G. 1994 - Tricholosporum in Mexico and description of a new species. Mycotaxon 50, 355-363.

Guzmán G, Montoya L, Bandala VM. 1990 - Observations on the genera Asproinocybe and Tricholosporum and description of new species of Tricholosporum (Agaricales, Tricholomataceae). Mycotaxon 38, 485-495.

Guzmán G, Ramirez-Guillen F, Contu M, Rodriguez O, Guzmán-Dávalos L. 2004 - New records of Asproinocybe and Tricholosporum (Agaricales, Tricholomataceae). Documents Mycologiques 33 (131), 23-28.

Halling R, Franco-Molano AE. 1996 - Agaricales from Costa Ricca: new taxa with ornamented spores. Mycologia 88, 666-670.

Heim R. 1970 - Breves diagnoses latinae novitatum genericarum specificarumque nuper descriptarum. Revue de Mycologie (Paris) 34, 343-347.

Heinemann P. 1977 - Un nouvel Asproinocybe (Tricholomataceae) du Zaire. Bulletin du Jardin Botanique National de Belgique 47, 265.

Heinemann P, Thoen D. 1977 - Asproinocybe (Tricholomataceae). In Flore illustrée des champignons d'Afrique centrale. Fasc. 5. Meise.

Hongo T. 1988 - On the genus Tricholoma of Japan. Transactions of the Mycological Society of Japan 29, 441--447.

Imai S. 1938 - Studies in the Agaricaceae of Hokkaido. Journal of the Faculty of Agriculture of the Hokkaido Imperial University 43, 1-178.

Josserand M. 1949 - Étude sur Tricholoma goniospermum Bres. In : Travaux botaniques dédiés à René Maire. Mémoires hors-série de la Société d'Histoire naturelle de l'Afrique du Nord, tome 2. Alger, 185-192.

Maire R. 1924 - Études mycologiques (fascicule 2). Bulletin de la Société Mycologique de France 40 (3), 293-317, pl. XVIII-XXII.

Maire R. 1945 - Études mycologiques (fascicule 5). Bulletin de la Société d'Histoire Naturelle de l'Afrique du Nord 33, 24-42.

Moreau PA, Contu M. 2007 - Une espèce remarquable de l'étage thermoméditerranéen de Corse et de Sardaigne: Tricholosporum cossonianum (Maire) comb. nov. Bulletin de la Fédération des Associations Mycologiques Méditerranéennes, n. s. 32, 41-52.

Murrill WA. 1938 - New Florida Agarics. Mycologia 30, 359-371.

Reid DA, Eicker A, Clémençon H, Roux C. 1998 - South African fungi 7: Tricholosporum laeteviolaceum sp. nov., a representative of a genus new to Southern Africa. Mycotaxon 69, 
$409-418$.

Ria A. 2008 - Tricholoma goniospermum. Primo ritrovamento per il territorio svizzero. Schweizerische Zeitschrift für Pilzkunde 86, 34-36.

Singer R. 1945 - New and interesting species of Basidiomycetes. Mycologia 37, 425-429.

Singer R. 1986 - The Agaricales in modern taxonomy, ed. 4. Königstein, Koeltz.

Thiers B. 2014 [continuously updated] - Index herbariorum: a global directory of public herbaria and associated staff. New York Botanical Garden's Virtual Herbarium. http://sweetgum.nybg.org/ih/

Thoen D. 1997 - Asproinocybe brunneolilacina, une nouvelle espèce d'agaricales d'Afrique Centrale. Bulletin du Jardin Botanique National de Belgique 47, 53-54.

Watling R. 1997 - Tricholosporum superbum: a new Malaysian agaric. Bollettino del Gruppo Micologico G. Bresadola n.s. 40, 485-490. 